\title{
Clinical profile of patients with myasthenia gravis followed at the University Hospital, Federal University of Minas Gerais
}

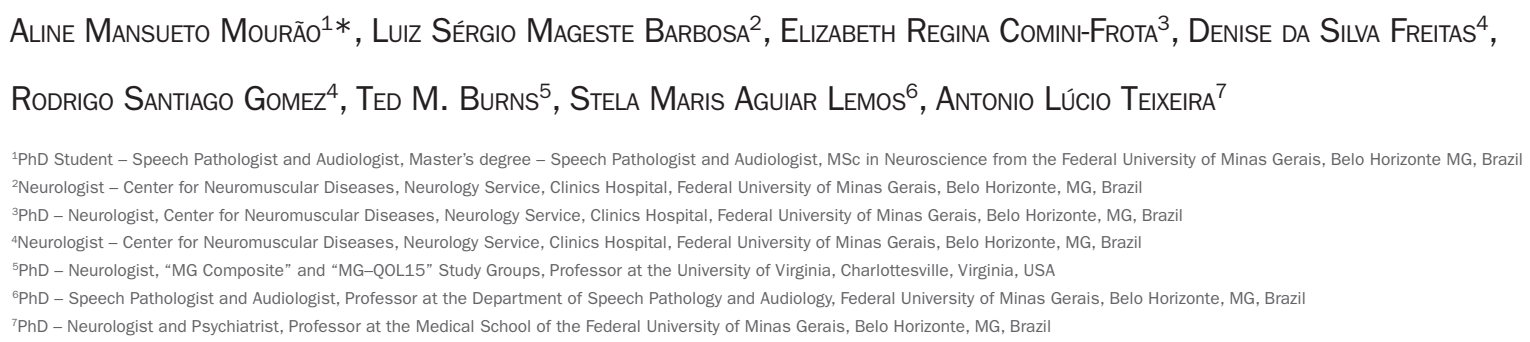

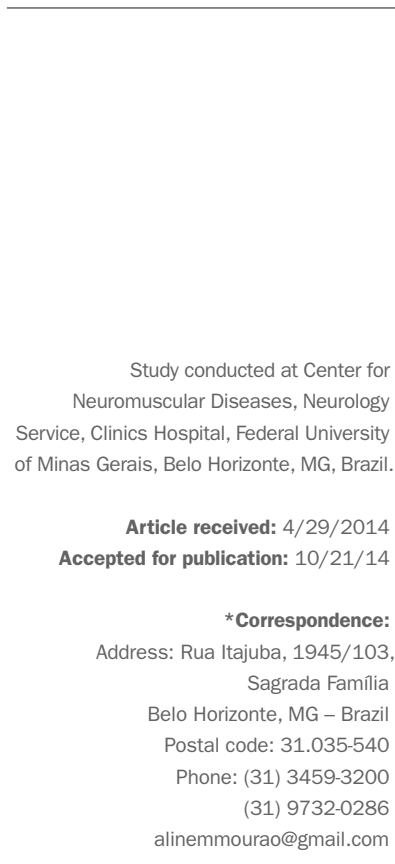

http://dx.doi.org/10.1590/1806-9282.61.02.156 Conflict of interest: none

\section{SUMMARY}

Objective: to determine the clinical profile of patients with myasthenia gravis (MG); followed at the Neuromuscular Diseases Clinic of the University Hospital, Federal University of Minas Gerais, Brazil, and to compare it with other Brazilian case series.

Methods: sociodemographic and clinical data were collected from patients, and a systematic literature review performed, focusing on national studies on the clinical profile of MG patients.

Results: sixty nine patients were enrolled in the study. Fifty five (91\%) subjects were female and the mean age (SD) was $37.6( \pm 11.4)$ years. The mean disease duration was 14.1 years. Regarding treatment, prednisone was the most used strategy (64\%), followed by the use of azathioprine (43\%). There was no difference between thymectomized (42) and non-thymectomized (27) patients regarding disease severity and medication use.

Conclusion: clinical and socio-demographic features of this MG sample from a University-based clinic resemble those reported in other Brazilian series and in the international literature.

Keywords: myasthenia gravis, epidemiology, neurology, thymectomy, therapeutics.

\section{INTRODUCTION}

Myasthenia gravis (MG) is a prototypical autoimmune disorder in which muscle weakness occurs as a result of the impairment in neuromuscular transmission. ${ }^{1}$ The main clinical symptoms are fatigue and fluctuating weakness of ocular, bulbar, respiratory, and appendicular muscles. ${ }^{2}$ This weakness tends to increase during the day and it is associated with physical activity, while muscle strength improves with rest or with anti-cholinesterase drugs. ${ }^{3-6}$ In most patients, the maximum level of severity is reached during the first three years of the disease. ${ }^{5-8}$

For the last 60 years, several epidemiological studies have been conducted on MG worldwide with great variability in the reported prevalence and incidence of the disease. Most of these studies were done in Europe and North America. ${ }^{9-16}$ These heterogeneous results may be partly explained by methodological differences and biological factors. ${ }^{17-23}$ There is, for instance, hormonal and/ or environmental influence on disease development.

There is no Brazilian study aiming to determine the prevalence of MG in the community. Conversely, a few Brazilian case series have been reported, describing clinical and sociodemographic features of patients followed at specialized clinics. ${ }^{17-30}$

The aim of the current study was to determine the clinical profile of patients with MG under treatment at the Neuromuscular Diseases Clinic of the University Hospital, Federal University of Minas Gerais (UFMG), com- 
paring it with other series to draw a picture of the MG in Brazil.

\section{Methods}

This is an observational cross-sectional study that collected data from 69 patients with MG followed at the Neuromuscular Diseases Clinic of the University Hospital, UFMG. Socio-demographic and clinical information was obtained through chart review and clinical evaluation.

Diagnosis of MG was based on the following criteria: clinical history of fatigability with recovery after rest, and clinical response to the administration of anti-cholinesterase drugs, associated with antibodies detection and/or decreased electrical activity in repetitive nerve stimulation, and exclusion of alternative neurological diseases. ${ }^{7,31}$

The severity of MG was graded according to the Myasthenia gravis Foundation of America Clinical Classification (MGFA). ${ }^{31}$ This scale was developed to identify subgroups of MG patients who share clinical features, possibly indicating similar prognosis and/or therapeutic response. It is now recognized as the main instrument to classify patients with MG, separating patients with purely ocular involvement from those with generalized or bulbar muscle weakness, specifying the degree of weakness in mild, moderate or severe.

Descriptive analysis was performed, reporting the frequency of all categorical variables, and analysis of the measures of central tendency and dispersion of continuous variables.

A systematic literature review was also carried out, selecting Brazilian studies that aimed to characterize and/or describe the clinical profile of patients with MG followed at outpatient services. The Medline and Lilacs databases were assessed. The following descriptors were used: Myasthenia gravis and Epidemiology; Myasthenia gravis and Therapeutics; Myasthenia gravis and Review; Myasthenia gravis and Prevalence, Incidence and Myasthenia gravis; Thymectomy and Epidemiology; Thymectomy and Therapeutics; Thymectomy and Review; Thymectomy and Prevalence, Thymectomy and Incidence. For the SciELO database, the same descriptors in Portuguese were used.

This study was approved by the Ethics Committee of the Federal University of Minas Gerais under ETIC license $\mathrm{n}^{\circ}$ 0476.0.203.000-11.

\section{RESULTS}

Sixty nine patients with MG were enrolled in this study (Tables 1 and 2). Most patients were women (91\%) with a female:male proportion of 4:1. Mean age (SD) was 37.6 $( \pm 11.4)$ years. According to the MGFA, Classes II A and V had the highest number of patients, with 14 in each class (20.3\%), followed by 13 patients (18.8\%) in Class I.

TABLE 1 Comparison of clinical and socio-demographic characteristics of thymectomized $(n=27)$ and nonthymectomized $(n=42)$ patients with myasthenia gravis.

\begin{tabular}{llll} 
Data & $\begin{array}{l}\text { Non- } \\
\text {-thymectomized }\end{array}$ & Thymectomized & $\begin{array}{l}\mathbf{P} \\
\text { value }\end{array}$ \\
\hline Gender & & & $\mathbf{0 . 2 2}$ \\
\hline Female & 30 & 25 & \\
\hline Male & 12 & 2 &
\end{tabular}

\begin{tabular}{|c|c|c|c|}
\hline Age & & & 0.36 \\
\hline $18-50$ & 31 & 23 & \\
\hline$>50$ & 11 & 4 & \\
\hline Years of disease & 14 & 14.2 & 0.55 \\
\hline First symptoms & & & 0.86 \\
\hline Ocular & 22 & 25 & \\
\hline Bulbar & 5 & 6 & \\
\hline Generalized & 5 & 6 & \\
\hline Main symptoms & & & 0.36 \\
\hline Ocular & 15 & 8 & \\
\hline Bulbar & 10 & 11 & \\
\hline Generalized & 13 & 12 & \\
\hline MFGA & & & 0.19 \\
\hline I & 9 & 4 & \\
\hline$\| \mathrm{A}$ & 10 & 4 & \\
\hline IIB & 2 & 0 & \\
\hline IIIA & 5 & 7 & \\
\hline IIIB & 3 & 7 & \\
\hline IV & 6 & 8 & \\
\hline $\begin{array}{l}\text { MG Composite } \\
(\text { mean } \pm \text { SD) }\end{array}$ & $7.2(4.7)$ & $8(5.1)$ & 0.75 \\
\hline $\begin{array}{l}\text { Number of crises } \\
(\text { mean } \pm S D)\end{array}$ & $3(1.2)$ & $9(1.6)$ & 0.07 \\
\hline
\end{tabular}

Treatment

0.75

Anticholinesterase 38

20

drug

\begin{tabular}{lll}
\hline Prednisone & 22 & 22 \\
\hline Azathioprine & 14 & 16 \\
\hline Plasmapheresis & 0 & 1 \\
\hline $\begin{array}{l}\text { Other } \\
\text { immunosuppressant }\end{array}$ & 6 & 3 \\
\hline
\end{tabular}

MG: myasthenia gravis; MGFA: Myasthenia gravis Foundation of America Clinical Classification Test Statistics; Mann-Whitney U; Fischer's Exact Test.

Regarding current treatment, 30 (43\%) were taking azathioprine, 9 (13\%) other immunosuppressants (6 cyclophosphamide; 3 cyclosporine), 1 (1.4\%) plasmapheresis, 
TABLE 2 Clinical profile of myasthenia gravis patients from Brazilian case series.

\begin{tabular}{|c|c|c|c|c|c|c|c|c|c|c|c|c|c|}
\hline & Study & $\mathbf{N}$ & F:M & $\begin{array}{l}\text { Age } \\
\text { (Mean) }\end{array}$ & $\begin{array}{l}\text { Length of } \\
\text { disease } \\
\text { (years) }\end{array}$ & Main symp & toms & & Treatme & & & & \\
\hline $\mathbf{R}$ & & & & & & O & B & G & $T$ & I & AZA & PDN & MS \\
\hline 25 & $\begin{array}{l}\text { Oliveira } \\
\text { et al. } 1995\end{array}$ & 52 & $6.4: 1$ & 27 & 3.1 & 0 & 0 & $\begin{array}{l}52 \\
(100 \%)\end{array}$ & $\begin{array}{l}52 \\
(100 \%)\end{array}$ & 0 & 0 & $\begin{array}{l}52 \\
(100 \%)\end{array}$ & 0 \\
\hline 17 & $\begin{array}{l}\text { Saraiva } \\
\text { et al. } 1996\end{array}$ & 324 & 2.1:1 & 34.6 & . & $62(19.1 \%)$ & $\begin{array}{l}16 \\
(4.9 \%)\end{array}$ & $\begin{array}{l}246 \\
(75.9 \%)\end{array}$ & $\begin{array}{l}16 \\
(4.9 \%)\end{array}$ & . & . & . & . \\
\hline 18 & $\begin{array}{l}\text { Cunha } \\
\text { et al. } 1999\end{array}$ & 153 & $2.1: 1$ & 32.1 & 6.2 & $103(67.3 \%)$ & $\begin{array}{l}121 \\
(79 \%)\end{array}$ & $\begin{array}{l}76 \\
(49.6 \%)\end{array}$ & $4(2.6 \%)$ & . & . & . & . \\
\hline 19 & $\begin{array}{l}\text { Asis } \\
\text { et al. } 1999\end{array}$ & 41 & $1: 1.4$ & 45 & 5 & $1(2.4 \%)$ & $\begin{array}{l}6 \\
(14.6 \%)\end{array}$ & $\begin{array}{l}10 \\
(24.4 \%)\end{array}$ & $\begin{array}{l}41 \\
(100 \%)\end{array}$ & . & $\begin{array}{l}9 \\
(21.5 \%)\end{array}$ & $\begin{array}{l}21 \\
(51.2 \%)\end{array}$ & $\begin{array}{l}10 \\
(24.4 \%)\end{array}$ \\
\hline 26 & $\begin{array}{l}\text { Almeida } \\
\text { et al. } 2000\end{array}$ & 90 & $3: 1$ & 28.2 & 3.4 & . & . & . & 0 & 0 & $\begin{array}{l}11 \\
(12.2 \%)\end{array}$ & 0 & $\begin{array}{l}79 \\
(87.8 \%)\end{array}$ \\
\hline 24 & $\begin{array}{l}\text { Morrita } \\
\text { et al. } 2001\end{array}$ & 18 & $1.2: 1$ & 7.3 & . & . & . & . & $\begin{array}{l}5 \\
(27.8 \%)\end{array}$ & . & $\begin{array}{l}1 \\
(5.6 \%)\end{array}$ & $\begin{array}{l}16 \\
(88.9 \%)\end{array}$ & . \\
\hline 20 & $\begin{array}{l}\text { Werneck } \\
\text { et al. } 2002\end{array}$ & 24 & $2.3: 1$ & 39.5 & 4.1 & 0 & $\begin{array}{l}23 \\
(95.8 \%)\end{array}$ & $1(4.1 \%)$ & $12(50 \%)$ & $\begin{array}{l}3 \\
(12.5 \%)\end{array}$ & $\begin{array}{l}4 \\
(16.7 \%)\end{array}$ & $\begin{array}{l}17 \\
(70.8 \%)\end{array}$ & 0 \\
\hline 27 & $\begin{array}{l}\text { Oda } \\
\text { et al. } 2002\end{array}$ & 22 & $6.3: 1$ & 37.8 & 7.3 & . & . & . & . & . & . & . & . \\
\hline 28 & $\begin{array}{l}\text { Saito } \\
\text { et al. } 2003\end{array}$ & 21 & $6: 1$ & 29.7 & 6 & . & . & . & 0 & . & . & . & . \\
\hline 21 & $\begin{array}{l}\text { Maffeis } \\
\text { et al. } 2004\end{array}$ & 26 & $2.7: 1$ & 28 & . & . & . & . & $\begin{array}{l}18 \\
(69.2 \%)\end{array}$ & . & . & . & . \\
\hline 22 & $\begin{array}{l}\text { Ruiz } \\
\text { et al. } 2004\end{array}$ & 46 & $2: 1$ & 30 & 26.3 & $4(8.7 \%)$ & $\begin{array}{l}22 \\
(47.8 \%)\end{array}$ & $\begin{array}{l}20 \\
(43.4 \%)\end{array}$ & $\begin{array}{l}46 \\
(100 \%)\end{array}$ & 0 & $\begin{array}{l}1 \\
(2.1 \%)\end{array}$ & $\begin{array}{l}7 \\
(15.2 \%)\end{array}$ & $\begin{array}{l}9 \\
(19.5 \%)\end{array}$ \\
\hline 23 & $\begin{array}{l}\text { Mega } \\
\text { et al. } 2005\end{array}$ & 15 & $2.7: 1$ & 35 & . & . & . & . & $\begin{array}{l}15 \\
(100 \%)\end{array}$ & . & . & . & . \\
\hline 29 & $\begin{array}{l}\text { Aguiar } \\
\text { et al. } 2010\end{array}$ & 122 & $2.2: 1$ & 31.9 & 8.9 & $6(4.9 \%)$ & 0 & $\begin{array}{l}111 \\
(94.1 \%)\end{array}$ & $\begin{array}{l}52 \\
(42.6 \%)\end{array}$ & 0 & $\begin{array}{l}40 \\
(32.8 \%)\end{array}$ & $\begin{array}{l}109 \\
(89.3 \%)\end{array}$ & $\begin{array}{l}122 \\
(100 \%)\end{array}$ \\
\hline 30 & $\begin{array}{l}\text { Lorenzoni } \\
\text { et al. } 2013\end{array}$ & 53 & 4.9:1 & 42.1 & 15.1 & $28(52.8 \%)$ & $\begin{array}{l}21 \\
(39.6 \%)\end{array}$ & $4(7.5 \%)$ & $\begin{array}{l}21 \\
(39.6 \%)\end{array}$ & 0 & $\begin{array}{l}46 \\
(86.7 \%)\end{array}$ & $\begin{array}{l}50 \\
(94.3 \%)\end{array}$ & $\begin{array}{l}52 \\
(98.1 \%)\end{array}$ \\
\hline & $\begin{array}{l}\text { Current } \\
\text { study }\end{array}$ & 69 & $4: 1$ & 37.6 & 14.1 & $\begin{array}{l}23 \\
(33.3 \%)\end{array}$ & $\begin{array}{l}21 \\
(30.4 \%)\end{array}$ & $\begin{array}{l}25 \\
(36.2 \%)\end{array}$ & $\begin{array}{l}27 \\
(39.1 \%)\end{array}$ & $\begin{array}{l}9 \\
(13 \%)\end{array}$ & $\begin{array}{l}30 \\
(43 \%)\end{array}$ & $\begin{array}{l}44 \\
(64 \%)\end{array}$ & $\begin{array}{l}58 \\
(84 \%)\end{array}$ \\
\hline
\end{tabular}

R: references; N: number of patients; F:M: female:male proportion; O: ocular; B: bulbar; G: generalized; T: thymectomy; I: immunosuppressant (except AZA); AZA: azathioprine; PDN: prednisone; SM: symptomatic medication (pyridostigmine).

44 (64\%) prednisone and 58 (84\%) with symptomatic drug (pyridostigmine). The use of prednisone associated with symptomatic medication was the most adopted strategy.

Despite no difference between thymectomized and non-thymectomized patients in demographic and clinical features (Table 2), all patients who underwent thymectomy reported improvement of symptoms and/or reduction of the frequency of myasthenic crises after the surgery. Two out of 27 (7.4\%) had thymoma.

Socio-demographic and clinical data from the Brazilian studies are shown in Table 2. Fourteen Brazilian studies with enough data to characterize the clinical profile of MG patients were found. Only one study was carried out in children and adolescents. ${ }^{24}$ The main clinical features are similar among the studies. Most patients were young and women. Men had a greater mean age of MG onset in comparison to women. Most patients presented ocular involvement as the first symptom, and approximately $85 \%$ of patients progressed with generalized and bulbar symptoms. Pyridostigmine was the most prescribed drug for MG, while prednisone and azathioprine were the most commonly adopted immunosuppressant strategies. 


\section{Discussion}

Overall, the profile of MG patients followed at the Neuromuscular Diseases Clinic of the University Hospital, UFMG was similar to those described in other Brazilian series, which were also specialized-center based, and in the international literature. ${ }^{17-30}$

Ocular symptoms were the first symptoms described by most MG patients; however, they were not considered the main problem with the disease progression. Bulbar symptoms were considered the most disabling, which is in agreement with some studies. ${ }^{2-4,17,18,27}$

Thymectomy is mandatory in MG patients with thymoma, which was identified in two patients in the current series. For patients without thymoma, uncontrolled studies suggest that thymectomy increases the likelihood of remission. There was no significant difference between thymectomized and non-thymectomized patients in clinical parameters which is concordant with other Brazilian reports. ${ }^{20,29,30}$ Indeed, several cross-sectional studies failed to find any significant difference between patients who underwent thymectomy and those under conservative treatment. ${ }^{5,9,12,20,21,24,29}$ In this scenario and taking into account the risks associated with the surgical procedure, the indication of thymectomy is frequently withheld. To solve this issue a multi-center, single-blind, randomized study, comparing thymectomy to no thymectomy in MG patients receiving prednisone, is underway (clinicaltrials. gov; identifier: NCT00294658).

Only the latest studies detailed the therapeutic strategies used, ${ }^{29,30}$ and they are concordant with the clinical practice in our clinic. In contrast, even recent Brazilian case series ${ }^{18,19,22,23,25,27,29}$ used the clinical classification of Osserman-Gerkins, while the recommended standards of clinical research on MG and the international literature have adopted MGFA since the early 2000s. ${ }^{21,30}$

\section{Conclusion}

Despite the clinical heterogeneity of MG, the clinical and demographic profiles and therapeutic strategies reported in Brazilian case series are quite similar. Further studies in different settings (i.e. clinical vs. community), with long-term follow-up and collection of clinical data with standardized instruments (e.g. MGFA and QOLMG-15) are warranted to better define the unmet needs of the Brazilian subjects with MG.

\section{ACKNOWLEDGMENTS}

This study was supported by CAPES, CNPq and Fapemig, Brazil. AMM received a CAPES scholarship during her
Master course. We would like to thank Dr. Izabela Barbosa for assistance in the systematic review of literature.

\section{Resumo}

Perfil clínico de pacientes com miastenia gravis em acompanhamento no Hospital das Clínicas, da Universidade Federal de Minas Gerais.

Objetivo: determinar o perfil clínico dos pacientes com miastenia gravis (MG) atendidos na Clínica de Doenças Neuromusculares do Serviço de Neurologia do Hospital das Clínicas da Universidade Federal de Minas Gerais, e comparar com outras séries de casos brasileiras.

Métodos: foram coletados dados clínicos e sociodemográficos dos pacientes, e realizada revisão sistemática de literatura, focando em estudos nacionais sobre o perfil clínico de pacientes com MG.

Resultados: sessenta e nove pacientes participaram do estudo, sendo 55 (91\%) do sexo feminino, e a média de idade (desvio-padrão) de 37,6 $( \pm 11,4)$ anos. O tempo médio de doença foi de 14,1 anos. Em relação ao tratamento, o uso isolado de prednisona foi a estratégia mais adotada (64\%), seguida do uso de azatioprina (43,3\%). Não houve diferença entre os pacientes timectomizados (47) e não timectomizados (22) no que diz respeito à gravidade da doença e ao tratamento.

Conclusão: as características clínicas e sociodemográficas da presente amostra de pacientes com MG de um serviço universitário assemelham-se às características de outras séries brasileiras e da literatura internacional.

Palavras-chave: miastenia gravis, epidemiologia, neurologia, timectomia, terapêutica.

\section{References}

1. Meriggioli MN, Sanders DB. Autoimmune myasthenia gravis: emerging clinical and biological heterogeneity. Lancet Neurol.2009;8(5):475-90.

2. Drachman DB. Myasthenia gravis. N Engl J Med. 1994;330(25):1797-810.

3. Grob D, Brunner N, Namba T, Pagala M. Lifetime course of myasthenia gravis. Muscle Nerve.2008;37(2):141-9.

4. Somnier FE, Keiding N, Paulson OB. Epidemiology of myasthenia gravis in Denmark. A longitudinal and comprehensive population survey. Arch Neurol.1991;48(7):733-9.

5. Beekman R, Kuks JB, Osterhuis HJGH. Myasthenia gravis: diagnosis and follow-up of 100 consective patients. J Neurol. 1997;244(2):112-8.

6. Robertson NP, Deans J, Comspton DAS. Myasthenia gravis: a population based epidemiological study in Cambridgeshire, England. J Neurol Neurosurg Psychiatry. 1998;65(4):492-6.

7. Donaldson DH, Ansher M, Horan S, Rutherford RB, Ringel SP. The relationship of age to outcome in myasthenia gravis. Neurology. 1990;40(5):786-90.

8. Mantegazza R, Beghi E, Pareuson P, Antozzi C, Peluchetti D, Sghirlanzoni A, et al. A multicentre follow-up study of 1,152 patients with myasthenia gravis in Italy. J Neurol. 1990;237(6):339-44. 
9. Rastenytė D, Vaitkus A, Neverauskas R, Pauza V. Demographic-clinical profile of the patients with Myasthenia gravis. Medicina (Kaunas). 2002; 38(6):611-6.

10. Carr AS, Cardwell CR, McCarron PO, McConville J. A systematic review of population based epidemiological studies in Myasthenia gravis. BMC Neurology. 2010;10(46):1-9.

11. Phillips LH 2nd: The epidemiology of myasthenia gravis. Ann N Y Acad Sci. 2003;998:407-12.

12. Heckmann JM, Owen EP, Little F. Myasthenia gravis in South Africans: racial differences in clinical manifestations. Neuromuscul Disord. 2007;17(1112):929-34.

13. Alshekhlee A, Miles JD, Katirji B, Preston DC, Kaminski HJ. Incidence and mortality rates of myasthenia gravis and myasthenic crisis in US hospitals. Neurology. 2009;72(18):1548-54

14. Sanchez JL, Uribe CS, Franco AF, Jimenez ME, Arcos-Burgos OM, Palacio LG. Prevalence of myasthenia gravis in Antioquia, Colombia. Rev Neurol. 2002;34(11):1010-2.

15. Phillips LH, Torner JC. Epidemiologic evidence for a changing natural history of myasthenia gravis. Neurology.1996;47(5):1233-8.

16. Jacobson DL, Gange SJ, Rose NR, Graham NM. Epidemiology and estimated population burden of selected autoimmune diseases in the United States. Clin Immunol Immunopathol. 1997; 84(3):223-43.

17. Saraiva PAP, Assis JL, Marchiori PE. Evaluation of the respiratory function in myasthenia gravis. Arq Neuropsiquiatr. 1996;54(4):601-7.

18. Cunha FMB, Scola RH, Werneck LC. Myasthenia gravis: clinical evaluation of 153 patients. Arq Neuropsiquiatr. 1999;57(2-B): 457-64.

19. De Assis JL, Zambon AA, Souza PS, Marchiori PE. Myasthenia gravis and thymoma Evaluation of 41 patients. Arq Neuropsiquiatr. 1999;57(1):6-13.

20. Werneck LC, Scola RH, Germiniani FMB. Myasthenic Crisis.Report of 24 cases. Arq Neuropsiquiatr. 2002;60(3-A):519-24.
21. Maffeis RC, Nucci A, Marques JFC, Roveri EG, Pfeilsticker BHM, Garibaldi SG, et al. Plasmaférese no tratamento da miastenia grave: estudo retrospectivo de 26 pacientes. Retrospective study of 26 patients. Arq Neuropsiquiatr. 2004;62(2-B):391-5.

22. Ruiz RLR, Reibscheid SM, Cataneo AJM, Rezende LAL. Extended thymectomy for treating patients with myasthenia gravis (MG). J Bras Pneumol. 2004;30(2):115-20.

23. Mega R, Coelho F, Pimentel T, Ribero R, Matos N, Araújo A. Thymus surgery in a general surgery department. Acta Méd Port. 2005;18(4):267-70.

24. Morrita MPA, Gabbai AA, Oliveira ASB, Penn AS. Myasthenia gravis in children. Analysis of 18 patients. Arq Neuropsiquiatr. 2001;59(3-B):681-5.

25. Oliveira JT, Campos GB, Cardoso FEC. Myasthenia gravis: results of thymectomy in 52 patients. Arq Neuropsiquiatr. 1995;53(2):198-202.

26. Almeida FHS, Okano N, Vargas EC, Ferreira-SantosR, SatoT, Barreira AA. Analysis of 90 cases treated with thymectomy. Acta Cir Bras. 2000;15(2):53-6.

27. Oda AL, Chiappetta ALML, Annes M, Marchesan IQ, Oliveira ASBO. Clinical, endoscopical and manometric evaluation of swallowing in patients with myasthenia gravis. Arq Neuropsiquiatr. 2002 60(4):986-95.

28. Saito EH, Higa C, Nunes RA, Magalhães GC, Vaz LCA, Cervante VF. Extended thymectomy through video assisted thoracic surgery and cervicotomy in the treatment of myasthenia. J Pneumol. 2003;29(5):273-9.

29. Aguiar AA, Carvalho AF, Costa CM, Fernandes JM, DAlmeida JA, Furtado LE, et al. Myasthenia gravis in Ceará, Brazil Clinical and epidemiological aspects. Arq Neuropsiquiatr. 2010;68(6):843-8.

30. Lorenzoni PJ, Augusto LP, Kamoi Kay CS, Scola RH, Werneck LC. Myasthenia gravis and thymus: long-termfollow-up screening of thymectomized and non-thymectomized patients. Arq Neuropsiquiatr. 2013;71(7):462-4.

31. Jaretzki A, Barohn RJ, Ernstoff RM, Kaminski HJ, Keesey JG, Penn AS, et al. Myasthenia gravis: recommendations for clinical research standards. Neurology. 2000;55(1):16-23 